\title{
PHYSICAL ACTIVITY AND PHYSICAL ABILITES TEST RESULTS BY ANTHROPOMETRIC CHARACTERISTICS OF APPLICANTS TO THE ESTONIAN ACADEMY OF SECURITY SCIENCES
}

\author{
EpP JALAKas, Mari JärVElaid
}

Estonian Academy of Security Sciences, University of Tartu, Tallinn, Estonia

\begin{abstract}
The purpose of this study was to assess the main health-related anthropometric characteristics of young adults in order to evaluate the relationship of their anthropometric characteristics with the quantity and type of physical activity and the physical abilities according to sex. The study was carried out using a sample of young adults applying to the Estonian Academy of Security Sciences (EASS) for programs which require physical ability tests upon application in order to ensure that public safety employees are capable of meeting the physical demands of their jobs.

The present study confirms that regular weekly physical activity is significantly correlated to body composition parameters as well as with the physical ability to perform fitness tests well.
\end{abstract}

Keywords: young adults, physical abilities test, anthropometrics, weight, height, body mass index, waist circumference, waist to hip ratio, waist to height ratio, bodyfat, obesity

\section{INTRODUCTION}

Physical abilities are necessary components of an officer's training program in the field of internal security and candidates have to pass the physical abilities tests (PAT) annually. PATs are used in many countries for their candidates and the cadets of the police, rescue and correctional services as well as military personnel.(1) Military personnel studies have shown a correlation between 
anthropometric parameters and blood pressure, as well as anthropometry and physical fitness to self-control. $(2,3,4)$ There is another important connection besides physical fitness to be kept in mind as well. It has been reported that waist to hip ratio (WHR) and waist to height ratio (WHtR) are the predictors of cardiovascular and metabolic risk factors. $(5,6)$ Obesity is one of the most common health problems in modern societies and is assuming epidemic proportions in both developed and developing countries. In 2012, for example $24.6 \%$ of Estonian males and $15.3 \%$ of females between the ages of $16-24$ had body mass index $\left(\mathrm{BMI}=\right.$ weight $/$ height $\left.^{2}\right)$ of more than $25 \mathrm{~kg} / \mathrm{m}^{2}$ and this trend is on the increase. (7) Several studies have reported lower BMI among the persons with higher levels of self-reported physical activity. $(8,9)$ Today the trend is towards increased phyical inacivity. For example, when in 2010 HBSC in Estonia asked 15-year-olds to report the number of days over the past week that they were physically active for a total of at least 60 minutes per day, only $13 \%$ of boys and $9 \%$ of girls answered positively. (10)

However, physically active individuals usually have a higher body density and fat free mass compared to physically inactive individuals, so body fat percentage, WHtR and waist circumference (WC) are supposed to have a greater discriminatory power compared to BMI (6).

The object of this paper is to find connections between self-reported physical activity, PAT results and anthropometric measures of EASS applicants.

\section{MATERIAL AND METHODS}

During the survey period, 2006-2014, 461 female and 695 male applicants of EASS voluntarily participated in anthropometric measurements. Weight was measured with a Tanita body composition monitor UM072 and height with a metallic measuring stick. WC was measured in centimetres without the compression of the soft tissue at the midway level between the lower rib margin and the iliac crest using a nonstretchable measuring tape (by precision \pm 0.5 $\mathrm{cm})$. The hip circumference (HC) was also measured in centimetres using the same measuring tape at the widest portion of the buttocks, with the tape parallel to the floor. Both measurements were taken while the subject was wearing little clothing, standing with feet closed together, arms at the side, body weight evenly distributed. The measurements were taken at the end of a normal expiration. All the measurments were taken by the same person.

WHR was calculated by taking the WC $(\mathrm{cm})$ and dividing by the $\mathrm{HC}(\mathrm{cm})$ and WHtR was calculated by taking WC $(\mathrm{cm})$ and dividing by height $(\mathrm{cm})$. 
Two excercises which have remained the same in EASS PAT in these years $-1500 \mathrm{~m}$ run and sit-ups - were included in the survey. The run was held on the same flat $500 \mathrm{~m}$ track where candidates run three laps every year. Sit-ups results were incorporated into this study only from those years where the candidates performed as many sit-ups as they could within two minutes without rest breaks.

The significant alpha for analyses was set at 0.05 . The Statistical Package for Social Sciences (SPSS) version 20 for Windows was applied to all the statistical analyses.

\section{Anthropometric characteristics}

The anthropometric characteristics of applicants who have participated in EASS entrance physical abilities tests during the period 2006-2014 are presented as follows.

Tabel 1. Anthropometric characteristics for male applicants ( $\mathrm{N}=695)$

\begin{tabular}{lcccc}
\hline & Mean & Std. Deviation & Minimum & Maximum \\
\hline Age $(\mathrm{yrs})$ & 20.3 & 3.47 & 17.0 & 46.0 \\
\hline Height $(\mathrm{cm})$ & 180.6 & 6.89 & 155.0 & 201.0 \\
\hline Body weight $(\mathrm{kg})$ & 77.6 & 12.09 & 46.2 & 139.9 \\
\hline Body Mass Index $\left(\mathrm{kg} / \mathrm{m}^{2}\right)$ & 23.7 & 3.23 & 14.7 & 41.2 \\
\hline Waist circumference $(\mathrm{cm})$ & 80.7 & 7.81 & 61.3 & 126.0 \\
\hline Hip circumference $(\mathrm{cm})$ & 100.5 & 6.95 & 71.7 & 162.5 \\
\hline Waist to hip ratio & 0.80 & 0.045 & 0.56 & 1.01 \\
\hline Waist to height ratio & 0.45 & 0.044 & 0.32 & 0.68 \\
\hline
\end{tabular}

The mean weight of the participating applicants by year of application to EASS during the years 2006-2014 is presented in Figure 1. The total body weight mean for males was $77.6 \mathrm{~kg}$ and for females $63 \mathrm{~kg}$. For males, the lowest mean weight $(75.0 \mathrm{~kg})$ was seen in 2006 and the highest one in $2010(80.6 \mathrm{~kg})$, a difference of $5.6 \mathrm{~kg}$. For females the lowest mean weight was seen in 2012 $(60.1 \mathrm{~kg})$ and the highest in $2008(65.6 \mathrm{~kg})$, a difference of $5.5 \mathrm{~kg}$. Statistically the significant correlation coefficent of male and female applicants height was 0.733 and weight 0.568 . 
Tabel 2. Anthropometric characteristics for female applicants $(\mathrm{N}=461)$

\begin{tabular}{lcccc}
\hline & Mean & Std. Deviation & Minimum & Maximum \\
\hline Age $(\mathrm{yrs})$ & 20.5 & 4.58 & 17.0 & 48.0 \\
\hline Height $(\mathrm{cm})$ & 167.2 & 6.12 & 146.0 & 189.5 \\
\hline Body weight $(\mathrm{kg})$ & 63.0 & 9.79 & 41.5 & 107.0 \\
\hline Body Mass Index $\left(\mathrm{kg} / \mathrm{m}^{2}\right)$ & 22.5 & 3.22 & 16.1 & 39.0 \\
\hline Waist circumference $(\mathrm{cm})$ & 71.9 & 7.24 & 48.3 & 103.0 \\
\hline Hip circumference $(\mathrm{cm})$ & 98.1 & 70.9 & 65.5 & 127.0 \\
\hline Waist to hip ratio & 0.73 & .045 & 0.58 & 0.91 \\
\hline Waist to height ratio & 0.43 & .046 & 0.12 & 0.61 \\
\hline
\end{tabular}

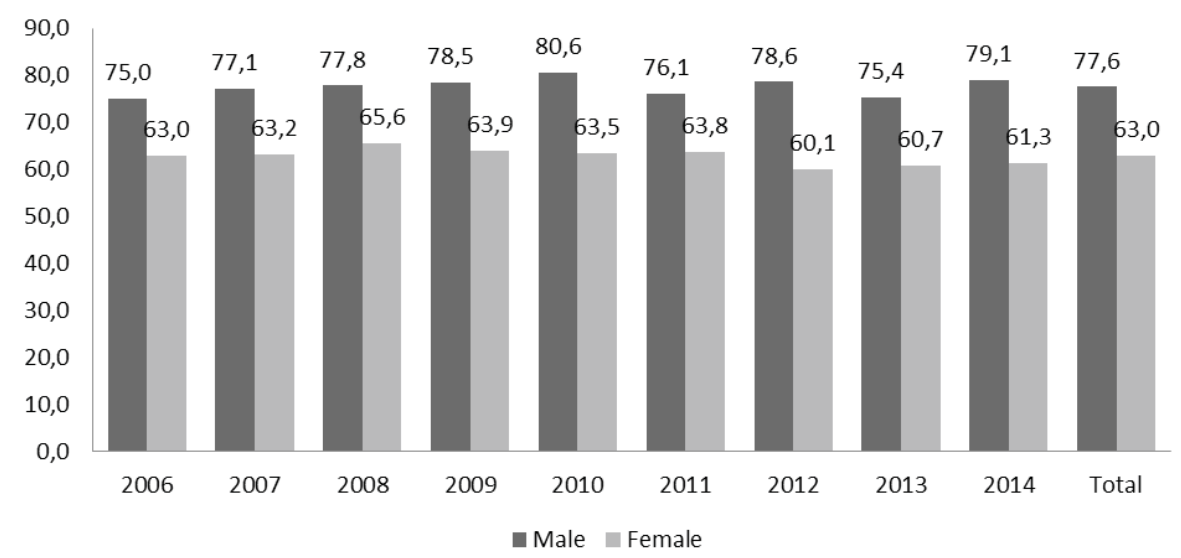

Figure 1. Mean weight (kg) of applicants by sex (2006-2014).

The height of applicants who participated in EASS entrance physical abilities tests during the period 2006-2014 is presented in Figure 2. The total mean height for males was $180.6 \mathrm{~cm}$ and for females, $167.2 \mathrm{~cm}$. For males, the lowest mean height $(179.8 \mathrm{~cm})$ was seen in 2006 and 2013 and the highest one (181.1 $\mathrm{cm}$ ) in 2008 and 2010, a difference of $1.3 \mathrm{~cm}$. For females the lowest mean height was seen in $2010(165.1 \mathrm{~cm})$ and the highest $(168.8 \mathrm{~cm})$ in 2013 , a difference of $3.7 \mathrm{~cm}$.

The means of WHR and the BMI $\left(\mathrm{kg} / \mathrm{m}^{2}\right)$ of the applicants is presented by age (in years) and sex in Table 3 . The total mean WHR was 0.80 for men and 0.73 for females. The mean BMI was $23.7 \mathrm{~kg} / \mathrm{m}^{2}$ for men and 22.5 for females. 


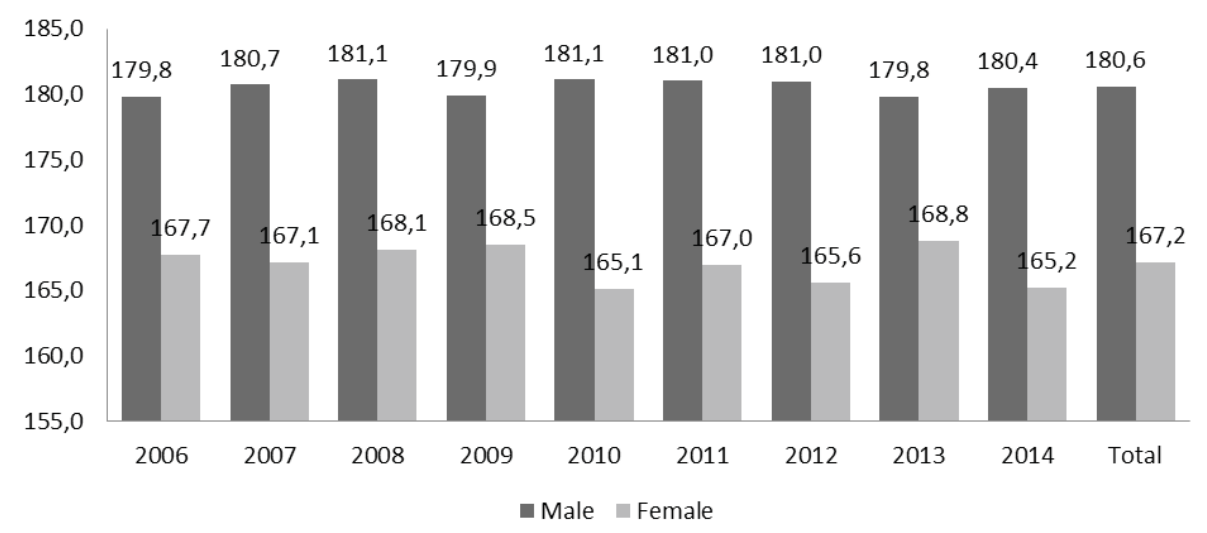

Figure 2. Mean height (cm) of applicants by sex (2006-2014).

Table 3. Means of waist to hip ratios and BMI by age and sex

\begin{tabular}{c|c|c|c|c}
\hline \multirow{2}{*}{ Age } & \multicolumn{2}{|c|}{ Male } & \multicolumn{2}{c}{ Female } \\
\cline { 2 - 5 } & WHR & BMI & WHR & BMI \\
\hline 18 & .79 & 23.5 & .73 & 22.2 \\
\hline 19 & .80 & 23.2 & .73 & 22.4 \\
\hline 20 & .80 & 23.6 & .73 & 22.7 \\
\hline 21 & .82 & 24.2 & .73 & 22.1 \\
\hline 22 & .82 & 24.9 & .74 & 23.3 \\
\hline 23 & .81 & 24.5 & .72 & 22.8 \\
\hline 24 & .82 & 24.3 & .75 & 21.9 \\
\hline 25 & .84 & 24.1 & .76 & 23.6 \\
\hline 26 & .83 & 25.2 & .78 & 25.4 \\
\hline 27 and over & .86 & 26.6 & .74 & 24.1 \\
\hline Total & .80 & 23.7 & .73 & 22.5 \\
\hline
\end{tabular}

The mean WHtR was 0,45 for male applicants and 0.43 for females (see Figure 3). 


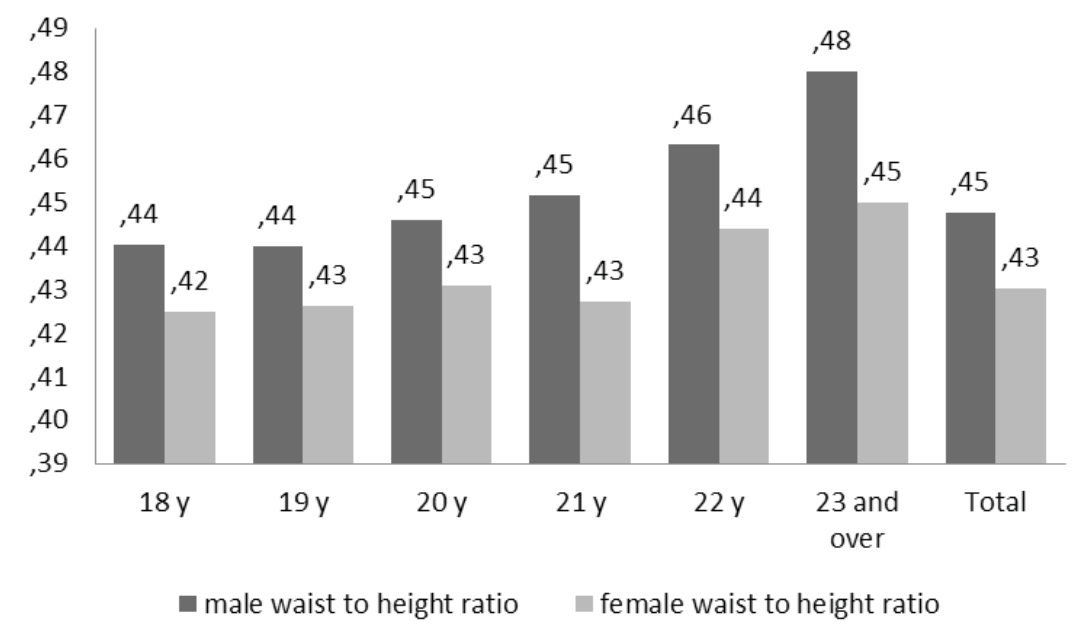

Figure 3. Mean waist to height ratio by age and sex.

\section{Sports activities}

The main sport discipline or disciplines were mentioned by $89 \%$ of subjects. However, $11 \%$ of subjects did not practice any discipline. The most popular sports disciplines among EASS applicants $(\mathrm{n}=1079)$ were running $(27 \%)$, weight training (17\%), soccer (16\%), basketball (12\%), cycling and volleyball (10\%).

Other endurance diciplines i.e swimming, skating, roller skating, skiing, orienteering, hiking and triathlon were mentioned by 151 subjects, fighting disciplines (boxing, kick-boxing, taekwondo, judo, karate, wrestling) by 94 subjects and track and field by 84 subjects. Altogether almost 50 disciplines were mentioned.

$76 \%$ of applicants reported that they practice sports at least $1-2$ hours per week.

Tabel 4. EASS applicants'sports hours per one week (by sex)

\begin{tabular}{lccc}
\hline & $\begin{array}{c}\text { Men } \\
(\mathbf{n = 6 5 0 )}\end{array}$ & $\begin{array}{c}\text { Women } \\
(\mathbf{n = 4 2 9 )}\end{array}$ & Total \\
\hline Very few or never & $7 \%$ & $17 \%$ & $11 \%$ \\
\hline 1 hour & $10 \%$ & $18 \%$ & $13 \%$ \\
\hline $1-2$ hours & $23 \%$ & $26 \%$ & $24 \%$ \\
\hline 3-7 hours & $39 \%$ & $31 \%$ & $36 \%$ \\
\hline 7 or more hours & $21 \%$ & $8 \%$ & $16 \%$ \\
\hline
\end{tabular}


$49 \%$ of male and $52 \%$ of female applicants participate in competitions but very few do this at the international level.

Tabel 5. Participation in competitions (by sex)

\begin{tabular}{lccc}
\hline & Men $\mathbf{n = 6 4 7}$ & $\begin{array}{c}\text { Women } \\
\mathbf{n}=\mathbf{4 2 8}\end{array}$ & $\begin{array}{c}\text { Total } \\
\mathbf{n}=\mathbf{1 0 7 5}\end{array}$ \\
\hline No participation & $51 \%$ & $48 \%$ & $50 \%$ \\
\hline Only school competitions & $10 \%$ & $22 \%$ & $15 \%$ \\
\hline Local competitons & $15 \%$ & $13 \%$ & $14 \%$ \\
\hline National competitions & $16 \%$ & $12 \%$ & $14 \%$ \\
\hline International competitions & $9 \%$ & $5 \%$ & $7 \%$ \\
\hline
\end{tabular}

Table 6. Results of $1500 \mathrm{~m}$ run by age and sex

\begin{tabular}{lcccccc}
\hline & \multicolumn{3}{c}{ Men } & \multicolumn{3}{c}{ Women } \\
\cline { 2 - 7 } Age & $N$ & Mean & Std. Deviation & $N$ & Mean & Std. Deviation \\
\hline 18 & 95 & $6: 09$ & $0: 35$ & 90 & $7: 32$ & $0: 56$ \\
\hline 19 & 306 & $6: 06$ & $0: 37$ & 175 & $7: 32$ & $0: 47$ \\
\hline 20 & 102 & $6: 00$ & $0: 34$ & 37 & $7: 18$ & $0: 45$ \\
\hline 21 & 42 & $6: 13$ & $0: 35$ & 18 & $7: 16$ & $0: 50$ \\
\hline 22 & 38 & $6: 16$ & $0: 38$ & 9 & $8: 18$ & $1: 16$ \\
\hline 23 & 24 & $5: 59$ & $0: 37$ & 9 & $7: 36$ & $0: 40$ \\
\hline 24 & 11 & $6: 37$ & $0: 41$ & 7 & $7: 37$ & $0: 25$ \\
\hline 25 & 9 & $5: 57$ & $0: 25$ & 8 & $7: 31$ & $1: 09$ \\
\hline$>=26$ & 30 & $6: 32$ & $0: 43$ & 32 & $8: 05$ & $1: 09$ \\
\hline
\end{tabular}

There was a statistically significant difference between male and female $1500 \mathrm{~m}$ run (-.710) and sit-ups results (.358). 


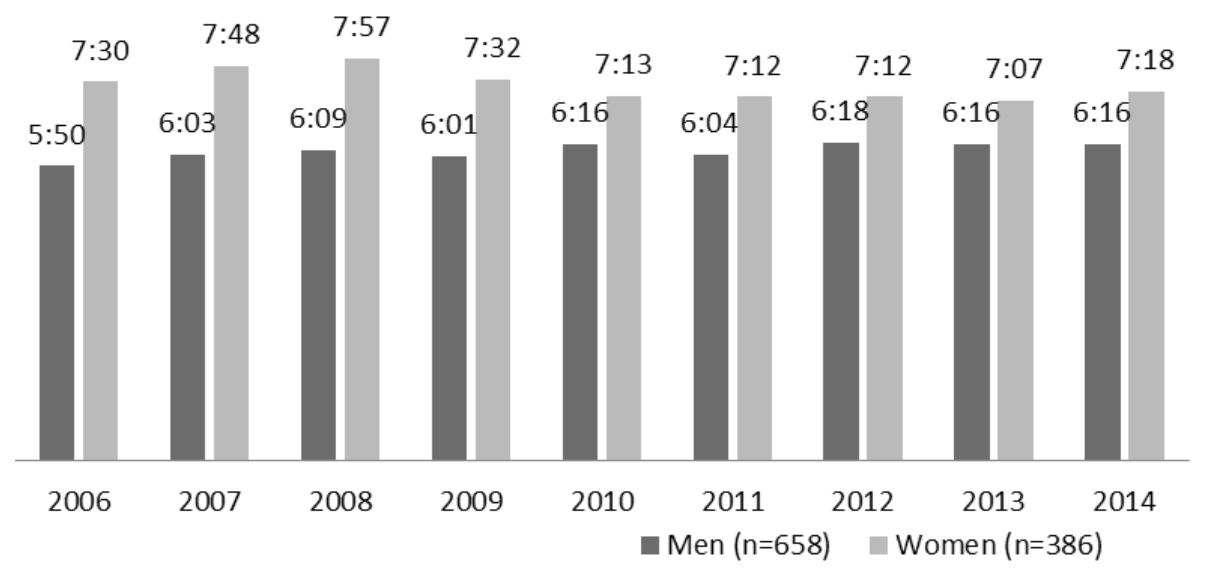

Figure 4. 1500m run mean results (min:s).

\section{RESULTS}

The female applicants' height and weight and male applicants' height were not statistically significant by age. Male weight significance coefficent by age was 0.175 . Other correlations regarding to age are presented in Table 7.

Table 7. Male and female applicants' correlation coefficents to their age

\begin{tabular}{lccccccccc}
\hline & $\begin{array}{c}\text { waist } \\
\text { cir- } \\
\text { cum- } \\
\text { ference }\end{array}$ & $\begin{array}{c}\text { hip cir- } \\
\text { cum- } \\
\text { ference }\end{array}$ & $\begin{array}{c}\text { sit-ups } \\
\text { peting } \\
\text { level }\end{array}$ & $\begin{array}{c}\text { prac- } \\
\text { ticing } \\
\text { sports } \\
\text { activity }\end{array}$ & $\begin{array}{c}\text { eating } \\
\text { break- } \\
\text { fast }\end{array}$ & $\begin{array}{c}\text { waist } \\
\text { to hip } \\
\text { ratio }\end{array}$ & $\begin{array}{c}\text { BMI } \\
\text { height } \\
\text { ratio }\end{array}$ \\
\hline Male &, $270^{* *}$ &, $161^{* *}$ &,$- 215^{* *}$ &, $215^{* *}$ &,$- 279^{* *}$ &, $154^{* *}$ &, $256^{* *}$ &, $185^{* *}$ &, $255^{* *}$ \\
\hline Female &, $128^{* *}$ & $\mathrm{Ns}$ & $\mathrm{Ns}$ & $\mathrm{Ns}$ &,$- 177^{* *}$ & $\mathrm{Ns}$ &, $115^{*}$ &, $097^{*}$ &, $124^{* *}$ \\
\hline
\end{tabular}

Ns - statis-

tically not

significant

* Correlation is significant at the 0.05 level (2-tailed).

** Correlation is significant at the 0.01 level (2-tailed).

The statistically significant correlation coefficent between WC and $1500 \mathrm{~m}$ run results for men was 0.234 and for women 0.226 . Between WC and sit-ups those connections were weaker: -0.179 (male) and -0.143 (female). 
Table 8. Sports activity hours per week (by age and sex)

\begin{tabular}{lcccccc}
\hline & \multicolumn{3}{c}{ Female } & \multicolumn{3}{c}{ Male } \\
\cline { 2 - 7 } Never & $\mathrm{N}$ & Mean age (yrs) & StD & $\mathrm{N}$ & Mean age (yrs) & StD \\
\cline { 2 - 7 } & 20 & 25.8 & 8.92 & 20 & 21.3 & 3.03 \\
\hline 0,5 hour & 53 & 21.5 & 6.01 & 24 & 22.7 & 5.62 \\
\hline 1 hour & 78 & 20.1 & 3.36 & 64 & 21.0 & 3.99 \\
\hline 1-2 hours & 110 & 19.9 & 3.58 & 151 & 20.2 & 2.67 \\
\hline 3-7 hours & 134 & 20.1 & 3.57 & 254 & 20.3 & 3.97 \\
\hline 7 or more hours & 34 & 21.1 & 5.97 & 137 & 19.5 & 1.73 \\
\hline Total & 429 & 20.6 & 4.64 & 650 & 20.3 & 3.43 \\
\hline
\end{tabular}

Older applicants tend to practice less sports (Table 8), although some were very active. Those who answered that they did not practice sports at all (20 men and 20 women) were with higher BMI than others. Men's mean BMI was respectively 24.5 (StD 3.97) for non-sporting group and varied from 23.6-24.0 (StD 2.79-5.1) in multi-level sports participants groups. For women those data were 25.7 (StD 5.86) versus 22.0-22.9 (StD 2.6-4.05).

The Spearman's correlation coefficient between men's sports hours per week and $1500 \mathrm{~m}$ run result was -0.30 and between the level of participation in competitions and $1500 \mathrm{~m}$ run result -0.34 . For women these results were -0.33 and -0.36 ( $\mathrm{p}<0.01$ in all cases). These data show the connection between practicing and results.

Since most of the candidates who failed in the $1500 \mathrm{~m}$ run were female, their anthropometric results were analyzed. There was a difference in the distribution of BMI - in the group of unsuccessful candidates there were more with a BMI over $25 \mathrm{~kg} / \mathrm{m}^{2}$ (Figure 5); also their mean WHR and WHtR were higher than in the womens group of those who passed the $1500 \mathrm{~m}$ run. Those mean results were - WHR 0.735 and 0.729 ; WHtR 0.438 and 0.423 . 


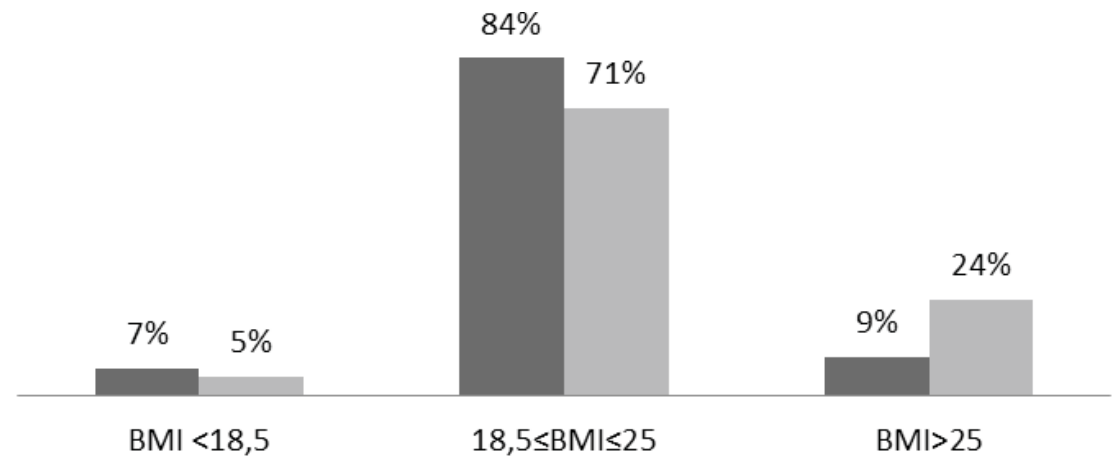

Women who passed $1500 \mathrm{~m}$ run Women who failed $1500 \mathrm{~m}$ run

Figure 5. Female BMI distribution of $1500 \mathrm{~m}$ run results.

The EASS entrance test results worsened as the sports activity or competition participation level of candidates decreased.

Tabel 9. EASS applicants' level of participation in competitions related to physical abilities tests results

\begin{tabular}{|c|c|c|c|c|c|}
\hline & & $\begin{array}{l}1500 \mathrm{~m} \\
\text { run men } \\
\text { (min:s) }\end{array}$ & $\begin{array}{c}1500 \text { m run } \\
\text { women } \\
\text { (min:s) }\end{array}$ & $\begin{array}{l}\text { Sit-ups } \\
\text { men (rep- } \\
\text { etitions) }\end{array}$ & $\begin{array}{l}\text { Sit-ups } \\
\text { women (rep- } \\
\text { etitions) }\end{array}$ \\
\hline \multirow{3}{*}{$\begin{array}{l}\text { No parti- } \\
\text { cipation }\end{array}$} & Mean & $6: 20$ & $7: 53$ & 44.1 & 37.0 \\
\hline & $\mathrm{N}$ & 307 & 172 & 202 & 152 \\
\hline & Std. D & $0: 38$ & $0: 58$ & 10.12 & 11.13 \\
\hline \multirow{3}{*}{$\begin{array}{l}\text { Only school } \\
\text { competitions }\end{array}$} & Mean & $6: 11$ & $7: 29$ & 44.2 & 39.8 \\
\hline & $\mathrm{N}$ & 60 & 76 & 41 & 68 \\
\hline & Std. D & $0: 32$ & $0: 43$ & 7.699 & 8.989 \\
\hline \multirow{3}{*}{$\begin{array}{l}\text { Local competi- } \\
\text { tons }\end{array}$} & Mean & $5: 58$ & $7: 12$ & 47.1 & 41.0 \\
\hline & $\mathrm{N}$ & 93 & 49 & 57 & 40 \\
\hline & Std. D & $0: 34$ & $1: 14$ & 6.51 & 10.12 \\
\hline \multirow{3}{*}{$\begin{array}{l}\text { National com- } \\
\text { petitions }\end{array}$} & Mean & $5: 52$ & 7:03 & 49.4 & 45.0 \\
\hline & $\mathrm{N}$ & 101 & 43 & 67 & 32 \\
\hline & Std. D & $0: 33$ & $0: 46$ & 7.54 & 10.72 \\
\hline
\end{tabular}




\begin{tabular}{llllll}
\hline & & \multicolumn{1}{c}{$\begin{array}{c}1500 \mathrm{~m} \\
\text { run men } \\
\text { (min:s) }\end{array}$} & $\begin{array}{c}1500 \text { m run } \\
\text { women } \\
\text { (min:s) }\end{array}$ & $\begin{array}{c}\text { Sit-ups } \\
\text { men (rep- } \\
\text { etitions) }\end{array}$ & $\begin{array}{c}\text { Sit-ups } \\
\text { women (rep- } \\
\text { etitions) }\end{array}$ \\
\hline \multirow{2}{*}{$\begin{array}{l}\text { International } \\
\text { competitions }\end{array}$} & Mean & $5: 48$ & $6: 53$ & 48.5 & 46.9 \\
\cline { 2 - 6 } & $\mathrm{N}$ & 52 & 22 & 31 & 8 \\
\cline { 2 - 6 } & Std. D & $0: 28$ & $0: 32$ & 11.50 & 11.09 \\
\hline \multirow{3}{*}{ Total } & Mean & $6: 08$ & $7: 34$ & 45.8 & 39.3 \\
\cline { 2 - 6 } & $\mathrm{N}$ & 613 & 361 & 398 & 300 \\
\cline { 2 - 6 } & Std. D & $0: 37$ & $0: 54$ & 9.38 & 10.81 \\
\hline
\end{tabular}

Tabel 10. Sports activity correlations with physical abilities tests results

\begin{tabular}{|c|c|c|c|c|c|}
\hline & & $\begin{array}{c}1500 \mathrm{~m} \\
\text { run men } \\
\text { (min:s) }\end{array}$ & $\begin{array}{c}1500 m \text { run } \\
\text { women } \\
\text { (min:s) }\end{array}$ & $\begin{array}{l}\text { Sit-ups } \\
\text { men (rep- } \\
\text { etitions) }\end{array}$ & $\begin{array}{c}\text { Sit-ups } \\
\text { women (rep- } \\
\text { etitions) }\end{array}$ \\
\hline \multirow{3}{*}{ Not at all } & Mean & $6: 30$ & $8: 39$ & 40.3 & 28.9 \\
\hline & $\mathrm{N}$ & 19 & 19 & 17 & 19 \\
\hline & Std. D & $0: 57$ & 1:18 & 7.72 & 11.55 \\
\hline \multirow{3}{*}{$<0,5 \mathrm{hr}$} & Mean & $6: 31$ & $8: 00$ & 35.9 & 34.3 \\
\hline & $N$ & 22 & 39 & 18 & 42 \\
\hline & Std. D & $0: 45$ & $0: 58$ & 7.60 & 9.94 \\
\hline \multirow{3}{*}{$0,5-1 \mathrm{hr}$} & Mean & $6: 24$ & $7: 44$ & 42.8 & 39.0 \\
\hline & $\mathrm{N}$ & 57 & 65 & 41 & 59 \\
\hline & Std. D & $0: 31$ & $0: 53$ & 9.33 & 9.33 \\
\hline \multirow{3}{*}{$1-2 \mathrm{hrs}$} & Mean & $6: 14$ & 7:33 & 44.3 & 40.0 \\
\hline & $\mathrm{N}$ & 146 & 95 & 95 & 71 \\
\hline & Std. D & $0: 37$ & $0: 43$ & 8.45 & 10.08 \\
\hline \multirow{3}{*}{$3-7$ hrs } & Mean & $6: 06$ & $7: 18$ & 47.0 & 42.3 \\
\hline & $\mathrm{N}$ & 238 & 111 & 149 & 86 \\
\hline & Std. D & $0: 32$ & $0: 43$ & 9.29 & 10.73 \\
\hline \multirow{3}{*}{$>7 \mathrm{hrs}$} & Mean & $5: 51$ & $6: 58$ & 50.0 & 45.4 \\
\hline & $N$ & 134 & 33 & 79 & 23 \\
\hline & Std. D & $0: 37$ & $0: 46$ & 8.69 & 10.11 \\
\hline
\end{tabular}


The $1500 \mathrm{~m}$ run and sit-ups mean results were constantly increasing by age and the yearly comparison showed that men's aerobic fitness results worsened in the last 3 years, whereas women's results showed a small improvement in the last 5 years as compared to the earlier period.

In most cases WHtR and WHR were correlated with other anthropometric measurments and physical tests results.

Table 11. WHtR and WHR correlations with other data (male $n=694$, female $n=461$ )

\begin{tabular}{lcccc}
\hline & WHtR male & WHtR female & WHR male & WHR female \\
\hline Age &, $255^{* *}$ &, $124^{* *}$ &, $256^{* *}$ &, $115^{*}$ \\
\hline Height &,$- 243^{* *}$ &,$- 247^{* *}$ &,$- 104^{* *}$ &,$- 180^{* *}$ \\
\hline Weight &, $590^{* *}$ &, $619^{* *}$ &, $380^{* *}$ &, $286^{* *}$ \\
\hline WC &, $872^{* *}$ &, $900^{* *}$ &, $663^{* *}$ &, $640^{* *}$ \\
\hline HC &, $636^{* *}$ &, $595^{* *}$ &, $197^{* *}$ & Ns \\
\hline Sit-ups &,$- 148^{* *}$ &,$- 114^{*}$ &,$- 128^{* *}$ & Ns \\
\hline $1500 m$ run &, $219^{* *}$ &, $199^{* *}$ &, $119^{* *}$ & $\mathrm{Ns}$ \\
\hline WHR &, $710^{* *}$ &, $696^{* *}$ & 1,000 & 1,000 \\
\hline BMI &, $841^{* *}$ &, $853^{* *}$ &, $497^{* *}$ &, $417^{* *}$ \\
\hline WHtR & 1,000 & 1,000 &, $710^{* *}$ &, $696^{* *}$ \\
\hline
\end{tabular}

Ns - statistically not significant, ${ }^{*}$ Correlation is significant at the 0.05 level (2-tailed), ${ }^{* *}$ Correlation is significant at the 0.01 level (2-tailed).

\section{DISCUSSION}

The mean height and weight of studied candidates who participated in the EASS entrance physical abilities tests do not vary statistically significantly by year. The total means for males were $77.6 \mathrm{~kg}$ and $180.6 \mathrm{~cm}$ and for females 63 $\mathrm{kg}$ and $167.2 \mathrm{~cm}$ and these anthropometric measures have mostly remained the same. As per the latest studies the mean weight of first year EASS male students ( $\mathrm{n}=57)$ in 1998 was $76 \mathrm{~kg}$ and mean height $181.4 \mathrm{~cm}$. For female students $(\mathrm{n}=41)$ the mean weight was $61.2 \mathrm{~kg}$ and mean height $166.7 \mathrm{~cm}$. (11)

Compared to Estonian schoolchildren growth charts 2006-2009, an EASS applicant's mean height has been approx. 1-2 cm shorter than for 18-19 year old girls and boys and their weight was approx. 2-3 kg heavier; (12) whereas compared to the Estonian Adult Population Study (2006-2012) for the 16-24 
age group the men's mean height varied from 181.0 to $182.3 \mathrm{~cm}$ and the women's height from 167.5 to $168 \mathrm{~cm}$, which is also higher than the mean heights in the EASS study. The mean weight of Estonian young adults showed a growth tendency from 75 to $77.6 \mathrm{~kg}$ for men and from 59.8 to $62.7 \mathrm{~kg}$ for women (Table 12).

Tabel 12. Estonian Adult Population Study (2006-2012), age group 16-24

\begin{tabular}{llcccc}
\hline Year of Study & & 2006 & 2008 & 2010 & 2012 \\
\hline Mean weight $(\mathbf{k g})$ & Men & 75 & 76.4 & 77.4 & 77.6 \\
\cline { 2 - 6 } & Women & 59.8 & 61.8 & 61.2 & 62.7 \\
\hline
\end{tabular}

The reason why the mean weight in the EASS study is larger than the mean weight of Estonian young adults could be explained by the applicants' heavier fatfree mass and also their older age. For example, in the EASS study women who were 21 or older $(\mathrm{n}=101)$ had a mean body weight of $64.7 \mathrm{~kg}$ (StD 11.2) and a height $166.9 \mathrm{~cm}$ (StD 6.4). By reducing the group to women aged 25 or older $(\mathrm{n}=47)$ the mean data were $66.6 \mathrm{~kg}(\mathrm{StD} 12.9)$ and $166.2 \mathrm{~cm}(\mathrm{StD} 6.6)$ respectively. For men 21 and older $(\mathrm{n}=170)$ these data were $81.3 \mathrm{~kg}$ (StD 13.0) and $180.6 \mathrm{~cm}$ (StD 6.6) and for men 25 and older, $(\mathrm{n}=46) 84.3 \mathrm{~kg}(\mathrm{StD} 15.5)$ and $180.4 \mathrm{~cm}$ (StD 7.9). Thus, older applicants weighed more than the younger ones.

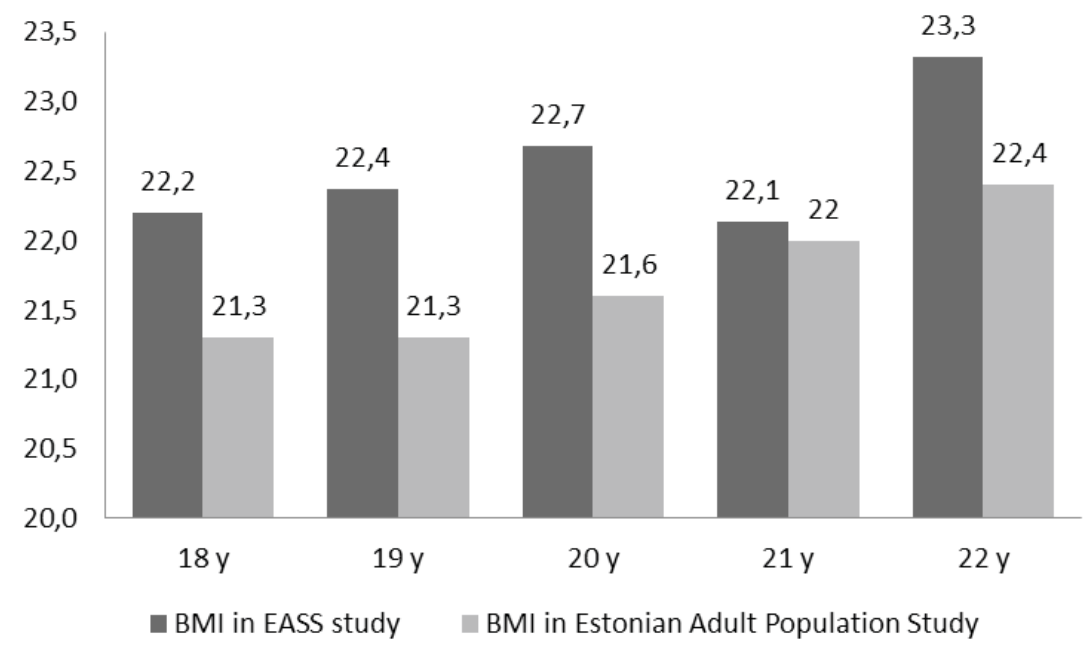

Figure 6. Female mean BMI values in the EASS study (2006-2014) and the Estonian Adult Population Study (2006-2012) 1 .

1 The data of Health Behavior among Estonian Adult Population Study are origin from Estonian National Institute of Health Development. 


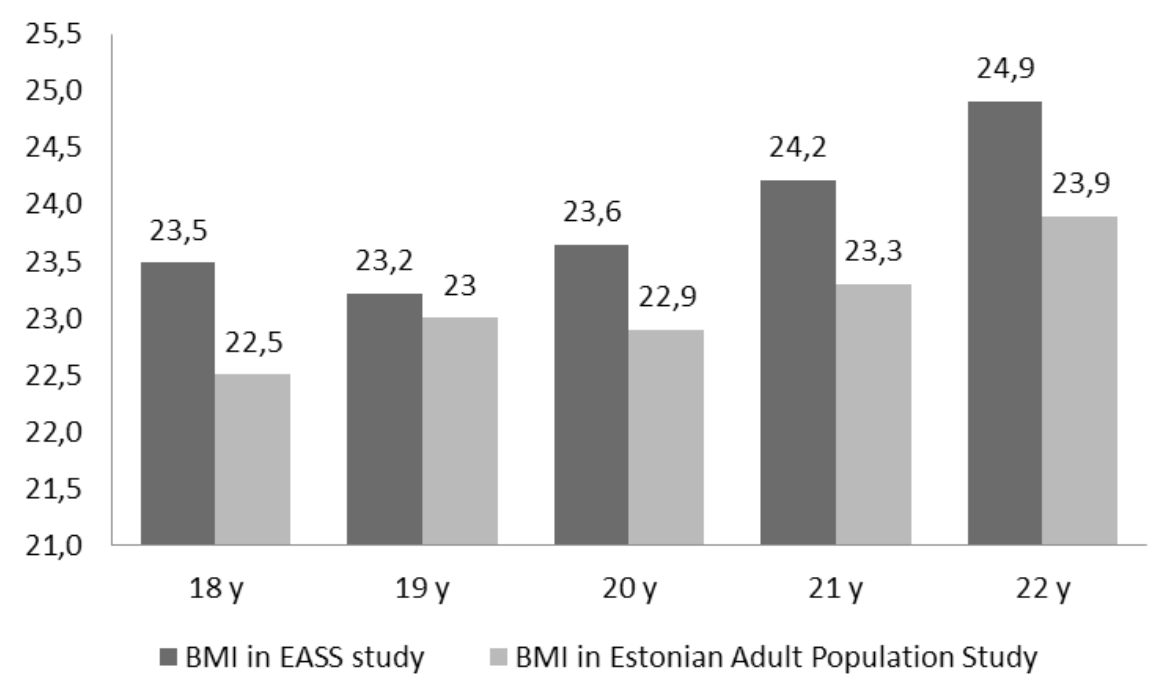

Figure 7. Male mean BMI values in the EASS study (2006-2014) and the Estonian Adult Population Study (2006-2012).

In the "Health Behavior among Estonian Adult Population Study" the mean BMI values of inactive persons were lower than the mean BMI values of those who practice sports. For example, in the years 2006-2012 Estonian 18-year-old women (25 respondents) who reported that they did not practice sports had a mean BMI of $20,8 \mathrm{~kg} / \mathrm{m}^{2}$ (StD 2.48) and the rest (99 respondents) a mean BMI of $21.4 \mathrm{~kg} / \mathrm{m}^{2}$ (StD 2.74). The mean BMI of 18 -year old inactive men (12 respondents) was $21.8 \mathrm{~kg} / \mathrm{m}^{2}$ (StD 3.31) and of the rest (85 respondents) $22.6 \mathrm{~kg} / \mathrm{m}^{2}$ (StD 3.0).

The prevalence of adiposity is more common in urban than in rural populations. Many studies have found that WC is a better predictor of metabolic syndrome than BMI (13) and WHtR scored over WC as a predictor of the metabolic syndrome and the coronary artery disease. (14)

According to the International Diabetes Federation the risk of metabolic syndrome for Europid men starts from WC $94 \mathrm{~cm}$ and for women from 80 $\mathrm{cm}$. In the EASS study 59 women and 42 men exceeded that limit. There were statistically significant differences between the normal and the risk group in mean weight, $\mathrm{HC}, \mathrm{BMI}, \mathrm{WHR}, \mathrm{WHtR}, 1500 \mathrm{~m}$ run and sit-ups results. Male applicants in the $\mathrm{WC} \geq 92$ group tend to practice statistically significantly less sports than the rest of the group which had a smaller WC. For female applicants this connection had no statistical significance at any WC point. 
A statistically significant correlation was observed between WC and cardiorespiratory fitness of young men in the study of Kawai et al.(15) Correlation coefficients in the EASS study were almost the same for male and female applicants (0.23).

Margaret Ashwell suggested boundary values of 0.5 and 0.6 for WHtR to indicate different levels of health risk in different age groups. (16) Rajesh Rajput and colleagues found in their study that the optimal cut-off of WHtR for the prediction of metabolic syndrome was 0.52 , offering a simple and reliable index of identifying individuals who face increased future risk of metabolic complications. $(17,18,6)$

There was a statistically significant difference in mean age, weight, WC, HC, WHR, BMI, 1500m run and sit-ups results between groups with $\mathrm{WHtR}<0.50(\mathrm{~N}=862)$ and $\mathrm{WHtR} \geq 0.50(\mathrm{~N}=127)$, but no statistically significant difference in sports activity in the EASS study. In sports activity a statistical significant difference was found between the groups with $\mathrm{WHtR}<0.52$ $(\mathrm{N}=926)$ and $\mathrm{WHtR} \geq 0.52(\mathrm{~N}=63)$ when looking at male and female groups together. That statistical significance was not found for male and female groups separately. It is possible that a WHtR of 0.52 and over could be caused by too little physical activity or simlpy that sports activity is less pleasant with such a level of obesity.

The correlation between sit-ups and $1500 \mathrm{~m}$ run tests results was higher among female candidates ( -0.42 female vs -0.39 male). The sequence of statistically significant anthropometric correlation coefficients with $1500 \mathrm{~m}$ run results was: female $\mathrm{HC}(0.25)$, male $\mathrm{HC}(0.24)$, male and female WC (0.23), male BMI and WHtR (0.22), male and female body weight (0.21), female BMI and WHtR (0.20), and male WHR (0.12). Those same connections with sit-ups results were weaker and WC, HC, BMI, WHR and WHtR were not statistically significantly connected to sports activity by sex.

It was found that sports activity and the participation level in competitions were more connected to run results than anthropometrical measures. Those participants, who practiced less sports, competed at a lower level or not at all, achieved lower results on physical tests. Quite a high correlation between sporting activity and performing physical tests was also found in earlier studies in EASS. (19)

The reason why EASS applicants' mean height remains smaller than in other similar Estonian groups could be that it is easier for shorter men and women to pass existing strength and running tests; thus taller candidates do not even bother to compete. EASS should examine whether existing PAT satisfy internal security departmental needs or there is a possibility for 
improvement. The recommended healthy BMI and bodyfat values as well as sports activity levels, should be introduced to applicants on EASS webpages to encourage them earlier into training in order to achieve better results in entrance tests.

The EASS applicants' sports activity seems to be higher than the Estonian average - only $48 \%$ of men and $52 \%$ of women went in for sports at least once a week (The Adult Population Study in 2012). Surveys in the field of internal security show that officers' tend to practice more sports than the average person. For example, the latest Estonian correctional officers sports activity study found that $87 \%$ of male and $67 \%$ of female correctional officers practised sports at least 2 hours per week, which is more than in the EASS applicants study. (20)

In the EASS study there are not many persons who compete at high levels. One of the reasons for the high percentage of sports activity could be the result of the necessity to train for entrance tests because the usual sports activity of Estonian young adults is not as high as the EASS study showed.

\section{CONCLUSION}

The present study confirms that regular weekly physical activity is significantly correlated to physical ability and body composition parameters and that athletic training is required to perform fitness tests well.

1. The EASS applicants' height was not statistically significantly correlated by age. Body weight was statistically significantly correlated by age only for male subjects.

2. Older applicants, especially men, tended to be less physically active.

3. The EASS applicants' physical tests mean results constantly worsened by age and were linearly related to applicants' physical activity and competition level.

4. The physical activity and the competing level of applicants had a more statistically significant connection to physical tests results than their anthropometric data.

5. A $\mathrm{WC} \geq 92$ for male applicants and $\mathrm{WHtR} \geq 0.52$ for all the subjects were found as prediction points of physical inactivity.

6. The statistically significant correlation coefficents of anthropometry (HC, WC, BMI, WHR, WHtR) showed a better connection for the $1500 \mathrm{~m}$ run than did sit-ups results and predicted that growing obesity influences aerobic fitness. 


\section{REFERENCES}

1. Jamnic V.K., Thomas S.G., Gledhill N. (2010). Applying the Meiorin Decision requirements to the fitness test for correctional officer applicants; examining adverse impact and accomodation. Appl Physiol Nutr 35, 71-81. Doi:10.1139/ H09-123.

2. Pl̦aviņa L. (2010). Evaluation of cadets' physical preparedness and fitness. Papers on Anthropology 19, 292-302.

3. Plavina L. (2009). Assessment of Functional Parameters of Health of the Military Personnel. Papers on Anthropology 18, 299-306.

4. Kinnunen M. I., Suihko J., Hankonen N., Absetz P and Jallinoja P. (2012). SelfControl is Associated with Physical Activity and Fitness among Young Males. Behavioral Medicine 38, 3, 83-89.

5. Bener A., Yousafzai M.T., Darwish S. et al. (2013). Obesity index that better predict metabolic syndrome: body mass index, waist circumference, waist hip ratio, or waist height ratio. Journal of Obesity. Article ID 269038 http://dx.doi. org/10.1155/2013/269038.

6. Zaccagni L., Barbieri D., Gualdi-Russo E. (2014). Body composition and physical activity in Italian university students. Journal of Translational Medicine. 12, 120. http://www.translational-medicine.com/content/12/1/120.

7. Health Behavior among Estonian Adult Population. www.tai.ee Tabel TKU40 Kehamassiindeks soo ja vanuserühma järgi.

8. Klumbiene J., Petkeviciene J., Helasoja V., Prättäla R., Kasmel A. (2004). Sociodemographic and health behaviour factors associated with obesity in adult populations in Estonia, Finland and Lithuania. European Journal of Public Health 14, 390-394.

9. DiPietro L.P. (1995). Physical activity, body weight and adiposity: an epidemiologic perspective. Exercise Sport Sci Rev 23, 275-303.

10. Social determinants of health and well-being among young people. Health Behaviour in School-aged Children (HBSC) study: international report from the 2009/2010 survey. Page 131. http://www.euro.who.int/__data/assets/ pdf_file/0003/163857/Social-determinants-of-health-and-well-being-amongyoung-people.pdf

11. Jalakas, E., Järvelaid, M. (2004). Relationship between anthropometric characteristics and physical performance among students at the Estonian Public Service Academy. Papers On Anthropology 13, 51-55.

12. Salm, E., Käärik, E., Kaarma, H. (2013) The growth charts of Estonian schoolchildren. Comparative analysis. Papers on Anthropology 22, 171-183.

13. Ferreira-Hermosillo, A., Ramírez-Rentería, C., Mendoza-Zubieta, V., \& MolinaAyala, M.A. (2014). Utility of the waist-to-height ratio, waist circumference and body mass index in the screening of metabolic syndrome in adult patients with type 1 diabetes mellitus. Diabetology \& Metabolic Syndrome, 6(1), 1-16. doi:10.1186/1758-5996-6-32. 
14. Nurus Sabah, K., Chowdhury, A., Luftur Rahman Khan, H.I., et al (2014). Body mass index and waist/height ratio for prediction of severity of coronary artery disease. BMC Research Notes, 7(1), 2-18. doi:10.1186/1756-0500-7-246.

15. Kawai, K., Takehisa H., Nobuhiro H. (2011). Relationship between Waist Circumference and Physical Fitness Factor in Young Men. Rigakuryoho Kagaku 26, 6, 739-742.

16. Ashwell, M. (2009). Obesity risk: importance of the waist-to-height ratio, Nursing Standard, 23, 41, 49-54.

17. Rajput R., Rajput M., Bairwa M., et al. (2014). Waist height ratio: a universal screening tool for prediction of metabolic syndrome in urban and rural population of Haryana. Indian Journal of Endocrinilogy and Metabolism. 18:394-399. Doi:10.4103/2230-8210.131201.

18. Bener A., Yousafzai M.T., Darwish S., et al. Obesity index that better predict metabolic syndrome: body mass index, waist circumference, waist hip ratio, or waist height ratio. Journal of Obesity, ID 269038, 9 pages, doi:10.1155/2013/269038.

19. Jalakas E., Järvelaid M. (2005). Relationship between practicing sports and performing physical tests at the Estonian Public Service Academy. Papers On Anthropology, 14, 112-116.

20. Jalakas, E.; Järvelaid, M.; Ööpik, V. (2014). Vanglaametnike kehaline võimekus: miks see oluline on ja kuidas ametnikud oma võimete arendamisse suhtuvad? Sisekaitseakadeemia Toimetised: Lisa, 12, 196-209.

\section{Address for correspondence:}

Epp Jalakas

Estonian Academy of Security Sciences

University of Tartu, Tallinn, Estonia

Kase Street 61, Tallinn 12012, ESTONIA

E-mail: epp.jalakas@sisekaitse.ee 